\title{
Utilization of Tofu Industry Waste and Banana Plant Waste for Growing Medium of Brown Oyster Mushrooms (Pleurotus cystidiosus [Jacq. Fr.] P.Kumm.)
}

\author{
Dian Indratmi*, Yossy Dian Kurniasari, Hartawati Hartawati, and Ali Ikhwan \\ Department of Agrotechnology, Faculty of Agriculture and Animal Science, \\ University of Muhammadiyah Malang, Jl. Raya Tlogo Mas no.246. Malang 65144, Indonesia
}

\begin{abstract}
Brown oyster mushroom is one of the consumption mushrooms with high economic value, so it is important to be cultivated commercially. Several types of plant and industrial wastes, such as dried banana leaves and tofu dregs, are available abundantly in the field. The waste has the potential to be used as medium for growing consumption mushrooms. This is because dried banana leaves and tofu dregs contain enough nutrients needed for the growth and development of oyster mushrooms. The study aimed to determine the growth response and yield of brown oyster mushrooms by giving various doses of dried banana leaves and tofu dregs flour. The research was carried out using factorial completely randomized design. First factor: dosage of tofu flour: $50 \mathrm{~g}$ per baglog, $150 \mathrm{~g}$ per baglog, and $250 \mathrm{~g}$ per baglog. Second factor: dosage of dried banana leaves, without dried banana leaves, $100 \mathrm{~g}$ dried banana leaves per baglog, and $250 \mathrm{~g}$ dried banana leaves per baglog. The results showed that the treatment of addition of tofu dregs flour with dried banana leaves interacted very significantly in the number of mushroom caps, diameter and thickness of the caps, the length of the mycelium, the fresh weight of the fungus, and biological efficiency.
\end{abstract}

Keywords: Biological efficiency, fungus, nutrient, waste.

\section{Introduction}

Brown oyster mushroom (Pleurotus cystidiosus [Jacq. Fr.] P.Kumm.) is a type of consumption mushroom that is popular with the public. Brown oyster mushrooms usually grow wild in nature and have not been widely cultivated. Oyster mushrooms are highly nutritious, have vitamin $\mathrm{B}, \mathrm{C}$ and $\mathrm{D}$, and that carry numerous medicinal benefits [1]. Brown oyster mushrooms have the advantage of thicker caps and longer shelf life [2].

Brown oyster mushroom has not been widely cultivated but the market demand for oyster mushroom continues to rise. Sawdust is a staple used as a growing medium in producing the fungus. Wood sawdust is a place to grow oyster mushrooms classified as fungi using cellulose, hemicellulose, and lignin that can break down and use it as a carbon source [3].

\footnotetext{
*Corresponding author: dian@umm.ac.id or indratmi_dian@yahoo.co.id
} 
Kind of growing media is very important because it can affect the results of oyster mushrooms later. Brown oyster mushroom media used must contain nutrients needed for growth and production including lignin, carbohydrates (cellulose and glucose), protein, nitrogen, fiber and vitamins. Other factors that influence the growth of brown oyster mushrooms are temperature, humidity, light intensity and $\mathrm{pH}$. Tofu waste and dried banana leaves are potential wastes to be used as additional growth media for consumption mushroom production.

Tofu waste is a waste from tofu processing. Tofu waste contains substances such as carbohydrates, proteins, fats, minerals and vitamins. Protein functions to stimulate mycelium growth, while fat is used as an energy source to break down carbohydrates, protein, minerals and vitamins. Tofu waste can provide earlier yields, more fruit bodies and increase fruit weight, so that at harvest time the results are better and more profitable [4].

Dried banana leaf contains hemicellulose so that it can be used as a mushroom growing media. The organic components of banana leaf (g per $100 \mathrm{~g}$ dry weight) are cellulose $11 \mathrm{~g}$; hemicellulose $20 \mathrm{~g}$; lignin $18.12 \mathrm{~g}$; total $\mathrm{C} 51$, and $\mathrm{C} / \mathrm{N}$ ratio 29.45 . Leaf waste is the best growing media for mushroom compared to other agricultural wastes such as coffee skins, reeds, and straw [5]. The addition of banana leaves waste to the wood sawdust base medium could increase the fresh weight of the white oyster mushroom fruit body. The contents of dried bananas consist of $16.0 \%$ dry matter, $2.3 \%$ crude protein, $3.7 \%$ crude fiber, $6.0 \%$ fat and $1.9 \%$ ash content two strains Volvariella volvacea [(Bul.) Singer,1951] showed their highest production on banana leaves waste, with biological efficiencies of $43 \%$ and $72 \%$ [6]. Seeing the potential of tofu industry waste and banana plants waste, it is important to research, its use as an additional growth medium for consumption mushrooms including brown oyster mushrooms.

\section{Materials and methods}

The study was conducted using a Completely Randomized Design (CRD) compiled factorially with two treatment factors, repeated four times.

First factor: Addition of tofu waste flour (A) consisting of three test levels, namely:

A1: $50 \mathrm{~g}$ tofu dregs flour per baglog

A2: $150 \mathrm{~g}$ tofu dregs flour per baglog

A3: $250 \mathrm{~g}$ tofu dregs flour per baglog

Second factor: Addition of dried banana leaves (D) consisting of three test levels, namely:

D0: without dried banana leaves

D1: $100 \mathrm{~g}$ dried dried banana leaf per baglog

D2: $250 \mathrm{~g}$ dried dried banana leaf per baglog.

Tofu industry waste in the form of tofu dregs is dried in an oven at $105{ }^{\circ} \mathrm{C}$ for $2 \mathrm{~d}$. Tofu dregs that have been dried mashed. Waste of banana plants in the form of dried banana leaves that are cut into small pieces so that it is easily inserted into plastic. The initial weight of the media grew by $800 \mathrm{~g}$.

The research data included observations of the growth of brown oyster mushroom mycelium (cm), number of mushroom caps, mushroom caps diameter $(\mathrm{cm})$, thickness of oyster mushrooms $(\mathrm{mm})$, fresh weight of mushrooms $(\mathrm{g})$, biological efficiency $(\%)$, and nutrient content analysis of tofu dregs. Harvesting is done four times. Specifically biological efficiency was measured after eigth times of harvest. 
The data obtained were then analyzed statistically using analysis of variance. To find out the effect of whether or not the F test level of $5 \%$ and $1 \%$ is used. If the F test results show a significant effect, then proceed with the Duncan Multiple Range Test.

\section{Results and discussion}

\subsection{Mycelium growth}

The data analysis showed that there were significant interactions at $(8,16,24,32$ and 40) $d$ after inoculation (DAI) on mycelium growth. The mean mycelium length is shown in Table 1.

Table 1. Average length of brown oyster mushroom mycelium due to addition tofu dregs flour and dried banana leaves (8 to 40) d After Inoculation (DAI)

\begin{tabular}{|c|c|c|c|c|c|}
\hline \multirow{2}{*}{ Treatment } & \multicolumn{5}{|c|}{ Mycelium growth $(\mathrm{cm})$} \\
\hline & 8 DAI & 16 DAI & 24 DAI & 32 DAI & 40 DAI \\
\hline $50 \mathrm{~g}$ flour, $0 \mathrm{~g}$ leaves & $0.63 \mathrm{bc}$ & $2.77 \mathrm{ab}$ & $6.16 \mathrm{ab}$ & $8.91 \mathrm{a}$ & $17.00 \mathrm{~b}$ \\
\hline $150 \mathrm{~g}$ flour, $0 \mathrm{~g}$ leaves & $1.23 \mathrm{~cd}$ & $5.26 \mathrm{~d}$ & $8.91 \mathrm{~d}$ & $11.94 \mathrm{bc}$ & $16.67 \mathrm{~b}$ \\
\hline $250 \mathrm{~g}$ flour, $0 \mathrm{~g}$ leaves & $0.00 \mathrm{a}$ & $4.16 \mathrm{~cd}$ & $8.71 \mathrm{~d}$ & $13.63 \mathrm{c}$ & $17.00 \mathrm{~b}$ \\
\hline $50 \mathrm{~g}$ flour, $100 \mathrm{~g}$ leaves & $2.30 \mathrm{e}$ & $7.51 \mathrm{e}$ & $12.60 \mathrm{e}$ & $17.00 \mathrm{~d}$ & $17.00 \mathrm{~b}$ \\
\hline $150 \mathrm{~g}$ flour, $100 \mathrm{~g}$ leaves & $1.48 \mathrm{~d}$ & $4.76 \mathrm{~cd}$ & $9.76 \mathrm{~cd}$ & $13.06 \mathrm{c}$ & $17.00 \mathrm{~b}$ \\
\hline $250 \mathrm{~g}$ flour, $100 \mathrm{~g}$ leaves & $0.00 \mathrm{ab}$ & $3.51 \mathrm{bc}$ & $8.42 \mathrm{~cd}$ & $13.09 \mathrm{c}$ & $17.00 \mathrm{~b}$ \\
\hline $50 \mathrm{~g}$ flour, $250 \mathrm{~g}$ leaves & $1.02 \mathrm{~cd}$ & $3.63 \mathrm{bc}$ & $6.82 \mathrm{~cd}$ & $9.66 \mathrm{ab}$ & $17.00 \mathrm{~b}$ \\
\hline $150 \mathrm{~g}$ flour, $250 \mathrm{~g}$ leaves & $0.00 \mathrm{ab}$ & $2.30 \mathrm{a}$ & $5.34 \mathrm{a}$ & $8.79 \mathrm{a}$ & $15.99 \mathrm{a}$ \\
\hline $250 \mathrm{~g}$ flour, $250 \mathrm{~g}$ leaves & $0.00 \mathrm{ab}$ & $2.26 \mathrm{a}$ & $5.42 \mathrm{ab}$ & $10.29 \mathrm{ab}$ & $16.03 \mathrm{a}$ \\
\hline
\end{tabular}

Numbers with the same letter in the same column are not significantly different according to the Duncan 0.05 test.

The $50 \mathrm{~g}$ tofu dregs flour and $100 \mathrm{~g}$ dried banana leaf treatment can accelerate the growth of fungal mycelium, so that at the age of 32 DAI mycelium fungi have filled the baglog. The addition of tofu waste flour and dried banana leaves on the mushroom growing media had a positive effect. Growth of oyster mushroom mycelium spread is influenced by nutrient content in the growing media. High protein content of $21.56 \%$ in tofu dregs indicates that the nitrogen content is also high so that the growth of mycelium becomes thick and compact (Table 2). Tofu waste contains carbohydrates, protein, fat, minerals and vitamins [7]. added that protein functions to stimulate mycelium growth.

Crude fiber in tofu dregs can increase the rate of mycelium spread, so it can supply the nutrients needed by the growth of fungal mycelium.

Table 2. Analysis of nutrient content of tofu waste

\begin{tabular}{|c|l|l|l|l|c|}
\hline Protein & Crude fat & Crude fiber & Dry matter & Water content & Ash \\
\hline $21.56 \%$ & $9.8 \%$ & $25.81 \%$ & $96.14 \%$ & $62.32 \%$ & $4.03 \%$ \\
\hline
\end{tabular}




\subsection{Number of mushroom caps}

The results of the analysis of variance showed a real interaction between the treatment of the amount of tofu dregs flour with dried banana leaves on the number of mushroom caps. The average number of caps for each treatment is presented in Table 3.

Table 3. Average number of brown oyster mushroom caps due to addition of tofu dregs flour and dried banana leaves.

\begin{tabular}{|l|c|c|c|c|c|}
\hline \multirow{2}{*}{ Treatment } & \multicolumn{5}{|c|}{ Number of mushroom caps } \\
\cline { 2 - 6 } & $\begin{array}{c}\text { Harvest } \\
\text { I }\end{array}$ & $\begin{array}{c}\text { Harvest } \\
\text { II }\end{array}$ & $\begin{array}{c}\text { Harvest } \\
\text { III }\end{array}$ & $\begin{array}{c}\text { Harvest } \\
\text { IV }\end{array}$ & $\begin{array}{c}\text { Average } \\
\text { harvest }\end{array}$ \\
\hline $50 \mathrm{~g}$ flour, 0 g leaves & $3 \mathrm{a}$ & $5 \mathrm{a}$ & $3 \mathrm{a}$ & $3 \mathrm{a}$ & $4 \mathrm{a}$ \\
\hline $150 \mathrm{~g}$ flour, $0 \mathrm{~g}$ leaves & $4 \mathrm{a}$ & $7 \mathrm{ab}$ & $5 \mathrm{a}$ & $4 \mathrm{ab}$ & $5 \mathrm{a}$ \\
\hline $250 \mathrm{~g}$ flour, $0 \mathrm{~g}$ leaves & $4 \mathrm{a}$ & $6 \mathrm{a}$ & $4 \mathrm{a}$ & $4 \mathrm{ab}$ & $4 \mathrm{a}$ \\
\hline $50 \mathrm{~g}$ flour, 100 g leaves & $4 \mathrm{a}$ & $7 \mathrm{ab}$ & $5 \mathrm{a}$ & $4 \mathrm{ab}$ & $5 \mathrm{a}$ \\
\hline $150 \mathrm{~g}$ flour, 100 g leaves & $4 \mathrm{a}$ & $6 \mathrm{a}$ & $4 \mathrm{a}$ & $4 \mathrm{ab}$ & $4 \mathrm{a}$ \\
\hline $250 \mathrm{~g}$ flour, 100 g leaves & $9 \mathrm{~b}$ & $9 \mathrm{~b}$ & $7 \mathrm{~b}$ & $6 \mathrm{~b}$ & $8 \mathrm{~b}$ \\
\hline $50 \mathrm{~g}$ flour, 250 g leaves & $4 \mathrm{a}$ & $6 \mathrm{a}$ & $4 \mathrm{a}$ & $4 \mathrm{ab}$ & $4 \mathrm{a}$ \\
\hline $150 \mathrm{~g}$ flour, 250 g leaves & $5 \mathrm{a}$ & $7 \mathrm{ab}$ & $5 \mathrm{a}$ & $4 \mathrm{ab}$ & $5 \mathrm{a}$ \\
\hline $250 \mathrm{~g}$ flour, 250 g leaves & $4 \mathrm{a}$ & $6 \mathrm{a}$ & $4 \mathrm{a}$ & $3 \mathrm{a}$ & $4 \mathrm{a}$ \\
\hline
\end{tabular}

Numbers with the same letter in the same column are not significantly different according to the Duncan 0.05 test.

The treatment of adding $250 \mathrm{~g}$ of tofu dregs flour and $100 \mathrm{~g}$ of dried banana leaves is able to provide sufficient nutrition so that it can form more primordia which will later become more fruit bodies. Nitrogen functions to form proteins, and builds enzymes for the growth of the fungus fruit caps. The crude fiber content of $25.81 \%$ in tofu waste flour (Table 2) can increase the production of cellulose enzymes so that cell formation occurs. The dried plants leaves contain high levels of hemicellulose and lignin [8].

Low or insufficient nutrient content can cause a less optimal growth of the primordial caps, making the growth in the number of caps to be small. The use of different planting media composition affects the physical quality of the oyster mushrooms produced [9].

\subsection{Mushroom caps diameter}

The results of the analysis of variance showed a very real interaction on the diameter parameters of the brown oyster mushroom caps. The average yield of each treatment is presented in Table 4.

Table 4. Average diameter of brown oyster mushroom cap due to addition of tofu dregs flour and dried banana leaves

\begin{tabular}{|l|l|l|l|l|l|}
\hline \multirow{2}{*}{ Treatment } & \multicolumn{5}{|c|}{ Caps diameter (cm) } \\
\cline { 2 - 6 } & $\begin{array}{c}\text { Harvest } \\
\text { I }\end{array}$ & $\begin{array}{c}\text { Harvest } \\
\text { II }\end{array}$ & $\begin{array}{c}\text { Harvest } \\
\text { III }\end{array}$ & $\begin{array}{c}\text { Harvest } \\
\text { IV }\end{array}$ & $\begin{array}{c}\text { Average } \\
\text { harvest }\end{array}$ \\
\hline $50 \mathrm{~g}$ flour, $0 \mathrm{~g}$ leaves & $8.58 \mathrm{c}$ & $7.42 \mathrm{f}$ & $6.76 \mathrm{c}$ & $5.60 \mathrm{~d}$ & $7.09 \mathrm{e}$ \\
\hline $150 \mathrm{~g}$ flour, $0 \mathrm{~g}$ leaves & $6.97 \mathrm{abc}$ & $5.97 \mathrm{cde}$ & $5.77 \mathrm{~b}$ & $5.18 \mathrm{bcd}$ & $5.97 \mathrm{~cd}$ \\
\hline $250 \mathrm{~g}$ flour, $0 \mathrm{~g}$ leaves & $7.72 \mathrm{bc}$ & $6.25 \mathrm{de}$ & $5.06 \mathrm{a}$ & $4.33 \mathrm{a}$ & $5.84 \mathrm{bcd}$ \\
\hline
\end{tabular}

(Continued on next page) 
Table 4. Continued

\begin{tabular}{|l|l|l|l|l|l|}
\hline \multirow{2}{*}{ Treatment } & \multicolumn{5}{c|}{ Caps diameter (cm) } \\
\cline { 2 - 6 } & $\begin{array}{c}\text { Harvest } \\
\text { I }\end{array}$ & $\begin{array}{c}\text { Harvest } \\
\text { II }\end{array}$ & $\begin{array}{c}\text { Harvest } \\
\text { III }\end{array}$ & $\begin{array}{c}\text { Harvest } \\
\text { IV }\end{array}$ & $\begin{array}{c}\text { Average } \\
\text { harvest }\end{array}$ \\
\hline $50 \mathrm{~g}$ flour, $100 \mathrm{~g}$ leaves & $6.06 \mathrm{ab}$ & $6.08 \mathrm{cde}$ & $5.71 \mathrm{ab}$ & $5.13 \mathrm{bcd}$ & $5.74 \mathrm{bcd}$ \\
\hline $150 \mathrm{~g}$ flour, $100 \mathrm{~g}$ leaves & $6.01 \mathrm{ab}$ & $5.83 \mathrm{bcd}$ & $5.44 \mathrm{ab}$ & $4.56 \mathrm{abc}$ & $5.46 \mathrm{abc}$ \\
\hline $250 \mathrm{~g}$ flour, $100 \mathrm{~g}$ leaves & $5.50 \mathrm{a}$ & $5.32 \mathrm{ab}$ & $6.67 \mathrm{c}$ & $5.32 \mathrm{~cd}$ & $5.70 \mathrm{abc}$ \\
\hline $50 \mathrm{~g}$ flour, $250 \mathrm{~g}$ leaves & $5.51 \mathrm{a}$ & $5.07 \mathrm{a}$ & $5.63 \mathrm{ab}$ & $4.75 \mathrm{abc}$ & $5.24 \mathrm{a}$ \\
\hline $150 \mathrm{~g}$ flour, $250 \mathrm{~g}$ leaves & $5.88 \mathrm{a}$ & $5.79 \mathrm{bc}$ & $5.37 \mathrm{ab}$ & $4.50 \mathrm{abc}$ & $5.39 \mathrm{ab}$ \\
\hline $250 \mathrm{~g}$ flour, $250 \mathrm{~g}$ leaves & $8.44 \mathrm{c}$ & $6.56 \mathrm{e}$ & $5.50 \mathrm{ab}$ & $4.67 \mathrm{abc}$ & $6.29 \mathrm{~d}$ \\
\hline
\end{tabular}

Numbers with the same letter in the same column are not significantly different according to the Duncan 0.05 test.

The treatment of adding $50 \mathrm{~g}$ of tofu dregs without the dry banana leaf has the highest diameter. This is allegedly because it is influenced by the number of caps formed. The $50 \mathrm{~g}$ tofu flour treatment without dried banana leaves has a smaller number of caps but the widest caps diameter. This shows that the growth of the caps is more maximal and the width of the caps is not crowded. The $50 \mathrm{~g}$ tofu dregs flour and $250 \mathrm{~g}$ dried banana leaves treatment has a relatively small diameter because the number of caps produced is quite large and crammed together to make the mushroom caps less optimal growth. The more mushroom caps that grow generally the smaller the diameter of the caps produced.

\subsection{Thickness of mushroom caps}

The results showed a significant interaction in the $1^{\text {st }}$ to $4^{\text {th }}$ harvest of the mushroom caps thickness. The average caps thickness of each treatment is presented in Table 5.

Table 5. Average thickness of brown oyster mushroom caps due to the addition of tofu waste flour and dried banana leaves

\begin{tabular}{|l|l|l|l|l|l|}
\hline \multirow{2}{*}{\multicolumn{1}{|c|}{ Treatment }} & \multicolumn{5}{c|}{ The thickness of caps (mm) } \\
\cline { 2 - 6 } & $\begin{array}{c}\text { Harvest } \\
\text { I }\end{array}$ & $\begin{array}{c}\text { Harvest } \\
\text { II }\end{array}$ & $\begin{array}{c}\text { Harvest } \\
\text { III }\end{array}$ & $\begin{array}{c}\text { Harvest } \\
\text { IV }\end{array}$ & $\begin{array}{c}\text { Average } \\
\text { harvest }\end{array}$ \\
\hline $50 \mathrm{~g}$ flour, $0 \mathrm{~g}$ leaves & $8.67 \mathrm{c}$ & $8.76 \mathrm{e}$ & $8.09 \mathrm{e}$ & $6.93 \mathrm{~d}$ & $8.11 \mathrm{c}$ \\
\hline $150 \mathrm{~g}$ flour, 0 g leaves & $6.13 \mathrm{a}$ & $7.31 \mathrm{c}$ & $7.10 \mathrm{c}$ & $6.51 \mathrm{bcd}$ & $6.76 \mathrm{ab}$ \\
\hline $250 \mathrm{~g}$ flour, $0 \mathrm{~g}$ leaves & $7.33 \mathrm{ab}$ & $7.59 \mathrm{~cd}$ & $6.39 \mathrm{~cd}$ & $5.66 \mathrm{a}$ & $6.74 \mathrm{ab}$ \\
\hline $50 \mathrm{~g}$ flour, $100 \mathrm{~g}$ leaves & $7.11 \mathrm{~b}$ & $7.41 \mathrm{~cd}$ & $7.04 \mathrm{~cd}$ & $6.46 \mathrm{bcd}$ & $7.01 \mathrm{~b}$ \\
\hline $150 \mathrm{~g}$ flour, $100 \mathrm{~g}$ leaves & $7.07 \mathrm{~b}$ & $7.16 \mathrm{bc}$ & $6.78 \mathrm{bc}$ & $5.90 \mathrm{abc}$ & $6.73 \mathrm{ab}$ \\
\hline $250 \mathrm{~g}$ flour, $100 \mathrm{~g}$ leaves & $6.56 \mathrm{ab}$ & $6.66 \mathrm{ab}$ & $8.00 \mathrm{ab}$ & $6.65 \mathrm{~cd}$ & $6.97 \mathrm{ab}$ \\
\hline $50 \mathrm{~g}$ flour, $250 \mathrm{~g}$ leaves & $6.57 \mathrm{~b}$ & $6.40 \mathrm{a}$ & $6.97 \mathrm{a}$ & $6.08 \mathrm{bcd}$ & $6.51 \mathrm{a}$ \\
\hline $150 \mathrm{~g}$ flour, $250 \mathrm{~g}$ leaves & $6.94 \mathrm{ab}$ & $7.12 \mathrm{bc}$ & $6.70 \mathrm{bc}$ & $5.82 \mathrm{ab}$ & $6.64 \mathrm{ab}$ \\
\hline $250 \mathrm{~g}$ flour, $250 \mathrm{~g}$ leaves & $6.66 \mathrm{ab}$ & $7.90 \mathrm{~d}$ & $6.84 \mathrm{~d}$ & $6.00 \mathrm{abc}$ & $6.85 \mathrm{ab}$ \\
\hline
\end{tabular}

Numbers with the same letter in the same column are not significantly different according to the Duncan 0.05 test

The thickness parameter of the $50 \mathrm{~g}$ tofu dregs treatment cap without dried banana leaves has the highest caps thickness with an average total value of $8.11 \mathrm{~mm}$. That is because in the growth of the number of fruit bodies, $50 \mathrm{~g}$ of tofu flour without tofu leaves produce a little and wider fruit caps so that the fungus can produce carbohydrates in sufficient quantities for vegetative growth. The more the number of caps, the thinner the 
caps thickness will be, causing the mushroom caps to be less than optimal. Mushrooms grow to form clumps, where if a large number of caps are formed in a clump, it will affect the diameter and thickness of the caps, ie the caps gets smaller.

\subsection{Mushroom fresh weight and biological efficiency}

The results showed a significant interaction between the addition of tofu dregs and dried banana leaves to the total fresh weight of mushrooms and biological efficiency. The average total fresh weight of mushrooms is presented in Table 6.

Table 6. Average fresh weight of brown oyster mushrooms due to addition of tofu dregs flour and dried banana leaves

\begin{tabular}{|l|c|c|}
\hline \multicolumn{1}{|c|}{ Treatment } & Fresh weight $(\mathbf{g})$ & Biological efficiency \%) \\
\hline $50 \mathrm{~g}$ flour, $0 \mathrm{~g}$ leaves & $121.67 \mathrm{a}$ & $46 \mathrm{~d}$ \\
\hline $150 \mathrm{~g}$ flour, $0 \mathrm{~g}$ leaves & $173.89 \mathrm{bc}$ & $55 \mathrm{ef}$ \\
\hline $250 \mathrm{~g}$ flour, $0 \mathrm{~g}$ leaves & $178.89 \mathrm{c}$ & $51 \mathrm{e}$ \\
\hline $50 \mathrm{~g}$ flour, $100 \mathrm{~g}$ leaves & $152.78 \mathrm{abc}$ & $48 \mathrm{de}$ \\
\hline $150 \mathrm{~g}$ flour, $100 \mathrm{~g}$ leaves & $137.78 \mathrm{ab}$ & $39 \mathrm{~b}$ \\
\hline $250 \mathrm{~g}$ flour, $100 \mathrm{~g}$ leaves & $230.00 \mathrm{~d}$ & $57 \mathrm{f}$ \\
\hline $50 \mathrm{~g}$ flour, $250 \mathrm{~g}$ leaves & $145.00 \mathrm{abc}$ & $40 \mathrm{~b}$ \\
\hline $150 \mathrm{~g}$ flour, $250 \mathrm{~g}$ leaves & $168.33 \mathrm{bc}$ & $42 \mathrm{bc}$ \\
\hline $250 \mathrm{~g}$ flour, 250 g leaves & $132.78 \mathrm{a}$ & $31 \mathrm{a}$ \\
\hline
\end{tabular}

Numbers with the same letter in the same column are not significantly different according to the Duncan 0.05 test.

Nutrients available in growing media that can be absorbed by the fungus will be able to increase the fresh weight of the fungus. The protein content in tofu dregs is thought to be able to add nutrients to the mushroom media. The cellulose and hemicellulose content in dried banana leaves can also stimulate tissue formation which affects the fresh weight of oyster mushrooms produced. It was suspected that mushrooms have sufficient energy reserves because the elements contained in baglog are evenly decomposed at the time of fruit body formation, thus affecting the fresh weight of mushrooms. The nutrients available in the growing media that are able to be absorbed by the fungus will be able to increase the fresh weight of the fungus. High protein content in tofu dregs increases the amount of nitrogen in the growing media so that it can spur the growth of white oyster mushroom mycelium. High nitrogen causes the growth of mycelium which is thicker and more compact [10].

The addition agricultural waste (leaves) to the base medium of wood sawdust can increase the fresh weight of the oyster mushroom body [11]. Nutritional requirements for oyster mushrooms are a source of carbon, nitrogen, and phosphate [12].

The higher the value of biological efficiency, the higher the production obtained and the more efficient use of the media by oyster mushrooms [13]. The treatment of adding $250 \mathrm{~g}$ flour and $100 \mathrm{~g}$ leaves has the best thickness of mycelium, which is dense and thick, mycelium which grows very thick can utilize the nutrients contained in the media well and efficiently. A good mycelium is mycelium that looks white like cotton, dense, and grows attached [14]. In the treatment with a higher total fresh weight of mushrooms, the biological efficiency value will also be higher. 


\section{Conclusion}

The interaction of the treatment of the addition of tofu dregs with dried banana leaves significantly affected the growth of mycelium, the number of caps, caps diameter, caps thickness, fresh weight, and the biological efficiency of brown oyster mushrooms. The treatment of adding $250 \mathrm{~g}$ of tofu dregs with $100 \mathrm{~g}$ dried banana leaves is a better treatment than others, which is shown with the highest fresh weight and biological efficiency.

\section{References}

1. B. Chakravarty. Australian J Agric. Eng., 2,4:102-109(2011). https://www.researchgate.net/publication/233735019_Trends_in_Mushroom_cultivati on_and_breeding

2. S. Carmen. Appl. Microbiol. Biotechnol., 85,5:1321-1337(2009). https://www.researchgate.net/publication/40444029_Cultivation_of_Pleurotus_ostreat us_and_other_edible_mushrooms

3. M. Syawal, S.A. Lasmini, Ramli. Int. J. Biol.Res., 2,1:156-161(2019). https://www.researchgate.net/publication/331087839_The_Effect_of_Bran_and_Corn _Flour_Composition_on_Swadust_Media_Materials_Towards_the_Growth_and_Res ult_of_White_Oyster_Mushroom_Pleurotus_ostreatus

4. H.T. Hoa, W.Chun-Li, W. Chong-Ho. Mycobiology, 43,4:423-434(2015). https://www.researchgate.net/publication/292205461_The_Effects_of_Different_Subs trates_on_the_Growth_Yield_and_Nutritional_Composition_of_Two_Oyster_Mushro oms_Pleurotus_ostreatus_and_Pleurotus_cystidiosus

5. K.M. Alananbeh, N.A. Bouqellah, N.S.A. Kaff. Saudi Journal of Biological Sciences, 21,6:616-625(2014). https://www.sciencedirect.com/science/article/pii/S1319562X1400093X?via\%3Dihub

6. M. Obodai, J.Cleland, P.Okine, N.T. Johnson. Tropical Sci., 43,3:121-124(2006). https://www.researchgate.net/publication/230148604_Use_of_agricultural_wastes_as_ substrate_for_the_mushroom_Volvariella_volvacea

7. R. Rambey, I.D.B. Sitepu, E.B.M. Siregar. IOP Conf. Ser.: Earth Environ. Sci. 260, 012076(2019).

https://iopscience.iop.org/article/10.1088/1755-1315/260/1/012076/pdf

8. S.B. Mukhopadhyay. Oyster Mushroom Cultivation on Water Hyacinth Biomass: Assessment of Yield Performances, Nutrient, and Toxic Element Contents of Mushrooms. (2019).p.13

https://www.researchgate.net/publication/338441296_Oyster_Mushroom_Cultivation _on_Water_Hyacinth_Biomass_Assessment_of_Yield_Performances_Nutrient_and_T oxic_Element_Contents_of_Mushrooms

9. S.S. Mkhize, J. Cloete, A.K. Basson, G.E. Zharare. Food Sci. Technol, 36,4:598605(2016).

https://www.researchgate.net/publication/311566558_Performance_of_Pleurotus_ostr eatus_mushroom_grown_on_maize_stalk_residues_supplemented_with_various_level s_of_maize_flour_and_wheat_bran

10. V. Barshteyn, T. Krupodorova. J. Microbiol. Biotech. Food Sci. 5,6:563-577(2016). https://www.researchgate.net/publication/303702219_Utilization_of_agroindustrial_waste_by_higher_mushrooms_modern_view_and_trends

11. Widiwurjani. Diversification of Oyster Mushroom (Pleurotus Ostreatus) Media From Agricultural Waste Materials. Proceedings Of The International Conference Of Fossa. (2017).p.96.

https://jurnal.unej.ac.id/index.php/prosiding/article/view/7950 
12. Mudakir, I and U.S.Hastuti. Agrivita, 37,1: 89-96(2015).

https://www.researchgate.net/publication/277592760_Study_of_wood_sawdust_with_ addition_of_plantation_wastes_as_a_growth_medium_on_yields_and_quality_of_whi te_oyster_mushroom

13. R.U. Priya, D.Geetha, S. Darshan. Adv. Life Sci. 5,22:10252-10254(2016). https://www.researchgate.net/publication/315727943_Biology_and_Cultivation_of_B1 ack_Ear_Mushroom_-_Auricularia_spp

14. T.R. Kinge, E.M. Adi, A.M. Mih, N.A.A che, T.M. Nji. African J. Biotechnol., 15,27:1476-1486(2016).

https://www.researchgate.net/publication/305452629_Effect_of_substrate_on_the_gro wth_nutritional_and_bioactive_components_of_Pleurotus_ostreatus_and_Pleurotus_fl orida 